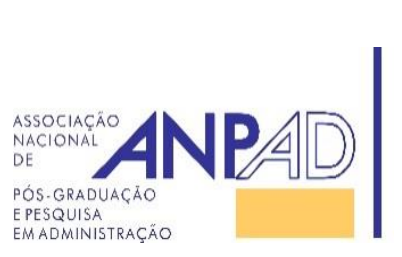
Available online at http://www.anpad.org.br/bar
BAR, Rio de Janeiro, v. 14, n. 4, art. 5, e170032, 2017
http://dx.doi.org/10.1590/1807-7692bar2017170032

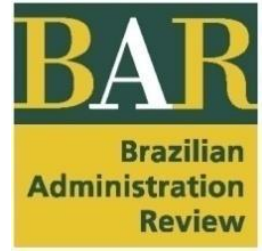

\title{
Productivity Antecedents of Brazilian Courts of Justice: Evidence from Justiça em Números
}

\author{
Alamir Costa Louro ${ }^{1}$ \\ Washington Romão Santos ${ }^{1}$ \\ Helio Zanquetto Filho ${ }^{1}$ \\ Universidade Federal do Espírito Santo ${ }^{1}$
}

Received 20 March 2017; received in revised form 14 October 2017; accepted 16 November 2017; first published online 13 December 2017. 


\begin{abstract}
Public sector managers and researchers have emphasized the importance of performance measurement. Nevertheless, few theoretical and empirical studies are found in Brazilian Judiciary Courts' literature. In order to empirically identify which variables (IT investments, own or outsourced human capital) are more relevant for improving productivity, the current research proposes a model using secondary data extracted from the Justiça em Números (Justice in Numbers) report, using structural equation modeling for the analysis. The results suggest that: (a) all variables are relevant for improving productivity in Brazilian Courts, confirming our first three theoretical hypotheses; and (b) own human capital has a greater impact on productivity than outsourced, confirming the fourth. For those who are responsible for reforms, this finding indicates that IT is not the most important investment. However a question remains: Seen as a cure for almost all problems in the public sector, is it possible to improve performance without hard IT investments? For future research there are some additional questions: Why is own human capital more relevant than outsourced? Which variables should be included in the model for improving the general significance? The answers can help improve Brazilian court productivity.
\end{abstract}

Key words: public administration; productivity; judiciary; IT investments; outsourcing; human capital. 


\section{Introduction}

In the last few decades, the government has given greater importance to management using statistical data as a fundamental tool in its reforms (Moynihan \& Hawes, 2012). For Brazilian judiciary organizations in particular, the adoption of indicators has often been encouraged by the National Justice Council (Conselho Nacional de Justiça [CNJ]) in the context of its audit reports, which seek to compile data on expenditures, investments, amount of human capital, and information related to judicial processes (CNJ, 2016). In fact, the CNJ resolutions are a fundamental component of these public reforms. Regarding judiciary organizational productivity, a relationship has been commonly assumed between statistical data and improved decision-making and accountability (Oliveira, 2012).

The present paper considers the theoretical bias of the New Public Administration and its orientation towards decision-making based on indicators and outsourcing practices, which is particularly true in the context of Courts of Justice, mainly when taking into account the criticisms of the refractory behavior towards changes in Brazilian judiciary organizations. Such organizations are also traditionally criticized for the inoperability and anachronism of their services, as portrayed by Sadek (2004) in pointing out that this is neither a current observation nor something common only in Brazil. One explanation for these criticisms is the lack of planning of public organizations in general, which has been an important issue for at least five decades. Article six of Decree-Law no. 200 (Decreto-Lei n. 200, 1967) advocates planning as a fundamental national public administration principle, suggesting observation of the efficiency and effectiveness in organizational resource allocation. This Decree-Law is a forerunner of the government management reform that began in the mid-1990s (Bresser-Pereira, 2009), and is relative to New Public Administration reforms. This same author affirms that new management frameworks initially used in private organizations were adapted to the reality of national public administration, aiming to reduce expenses and improve services.

In literature inspired by New Public Administration, however, what is widely adopted either a normative stance - indicating the best practices of possible reforms - or a descriptive stance - presenting the characteristics of some specific reforms (Bresser-Pereira, 2009). With regards to this, the national judiciary is no exception. Currently, as a consequence of research about reforms specifically based on $\mathrm{CNJ}$ resolutions, little systematic evidence has been produced on outsourcing and IT investments. Conversely, the present research has produced some empirical evidence on such topics as the association between own and outsourced human capital, IT investments, and productivity in Brazilian Courts of Justice.

In response to the gap in empirical research on the judiciary, and with the same view of Sadek and Oliveira (2012) who call for more research based on statistical indicators in these organizations, the present work adopts a quantitative approach and investigates the possible determinants of national judiciary productivity. More specifically, this paper's objective is to propose and empirically test a model based on public data of the Justiça em Números CNJ's report using the most primary antecedent for judicial performance: its own and outsourced human capital. Moreover, the motivation of the study to encompass IT Investments is twofold. On the one hand, the public sector underwent significant managerial reforms, and IT Investments represent great expectations for improving the productivity of the national judiciary (Gomes \& Guimarães, 2013). On the other hand, CNJ highlighted these investments as an important part $-25.1 \%$ - of the total expenditures of the national judiciary (CNJ, 2016).

The productivity of the courts is complex and can be influenced by different factors. Yeung and Azevedo (2011) have identified that efficient courts are those that best manage their resources. However, there is little empirical research on the influence of each of the resources in Brazilian courts, for example, investments in IT, own and outsourced human capital, and productivity. In this way, the study aims to deepen knowledge on productivity in Public Administration, focusing on data from state courts and providing a model that can interpret the data of such reports. 
According to a bibliographical review of national journals, with Qualis B3 ranking or higher, and corroborating the previous work carried out by Akutsu and Guimarães (2012), judiciary management is considered poorly explored, especially regarding IT investments and outsourcing. This paper aims to increase existing knowledge about IT investment and productivity in order to provide useful indications for these courts' top managers and the legislators of judiciary reforms.

\section{Theoretical Review}

Productivity is a multifaceted concept and little explored in the literature on the Brazilian judicial system, due to the difficulty or scarcity of data for analysis. In addition, efficiency and productivity literature focuses on DEA, data envelopment analysis, which takes the basis of a court as a benchmark and makes comparisons across other courts. Although pertinent, the objectives of the research would not be adequate, considering the present focus on the relationship between some latent variables like IT investments and court productivity, as well as distinguishing between own and outsourced human capital.

In order to understand judiciary productivity, it is necessary to know the impact of IT Investments, as well as own and outsourced human capital. This session will present the concepts that will support model structuring to analyze the results from research. This will take place by contextualizing the relationship between judiciary productivity and IT investments and the amount of outsourced and own human capital that is characterized as effective servants, judges, and commissioners.

For an introduction and history on statistical data in the judiciary, we suggest the work of Sadek and Oliveira (2012). Academic papers that address empirical data on the national judiciary have advanced little in analysis, and have given more focus to providing a description of the national scenario (Gomes \& Guimarães, 2013; Nogueira, Oliveira, Vasconcelos, \& Oliveira, 2012; Oliveira, 2012), or analyzing state courts (Gomes, Guimarães, \& Akutsu, 2017). Emphasis should be given to Gomes and Guimarães (2013), who published a bibliometric article on judiciary performance focusing on specific roles judges have, an approach that the present work seeks to overcome. In addition, international literature offers a few empirical works (Beenstock \& Haitovsky, 2004; Dimitrova-Grajzl, Grajzl, Sustersic, \& Zajc, 2012; Gomes et al., 2017; Ippoliti, Melcarne, \& Ramello, 2015; Mitsopoulos \& Pelagidis, 2007); however, they provide evidence that is still rather limited, usually circumscribed to economic variables, and sometimes with inconclusive results.

\section{IT Investments}

According to Galliers and Leidner (2003), as IT increased its capacity to generate and store information cheaply, its use quickly spread in organizations. Today, with the advent of data warehouses and business intelligence tools and concepts, different hierarchical levels of management can use indicators as a tool for decision-making. The large volume of data produced and processed by the organizations shows the need for storing and analyzing this data to gather better information that allows better decision making. In the context of the judiciary, Peyrache and Zago (2016) studied the inefficiency in Italian courts and identified that technological innovations could increase the efficiency level in the courts.

Caldeira, Serrano, Quaresma, Pedron, and Romão (2012) discuss some controversies regarding IT Investments and assert that in their case study, the relationship between this construct and organizational performance was considered positive. Gomes and Guimarães (2013) predict that, in general, in the judiciary, the increase in financial resources does not guarantee an increase in performance, an assessment that is supported by Heeley and Jacobson (2008) in private companies, since resources alone would not be able to generate competitive advantages (Bronzo et al., 2013). From 
this controversy, the present paper launches a partial result that will be studied in the future using other constructs related to IT investment, such as business process automation (Trkman, 2010) and IT corporate governance (Mohamed, 2012).

\section{Amount of Outsourced and Own Human Capital}

Human Capital refers to knowledge that is intrinsic to people and which is related to their capacities, skills, experiences, creativity, and innovation (Cassol, Gonçalo, \& Ruas, 2016). The digital revolution has influenced the way humanity relates to the world and how people access services. Digital services offer ways for people to modify existing processes and adjust data to the needs of society. The electronic judicial process was implemented with the objective of speeding up the services offered by the judiciary. The CNJ aims to computerize the judiciary as a way to respond to the demands of society more productively. However, computerization is the result of dialogue and consensus among legal operators, which may explain the resistance in some IT investments like electronic judicial process. As long as there is not sufficient artificial intelligence to process the actions in the national judiciary, there will be dependence on human capital to carry out the tasks. This human capital is detailed in specific indicators of the Justiça em Números report as employees, judges, commissioners, and outsourced staff. Therefore, in principle, the work of everyone can directly affect the Courts of Justice performance.

The idea that there are different productivities due to different human groups may be related to the level of commitment each group has to the organization (Carson, Carson, \& Bedeian, 1995). The results of Gomes and Guimarães (2013) allude to the importance of human capital in the productivity and speed of the courts. These and other works give more detail regarding the participation of the judges, while not dealing with differences in productivity between outsourced and own human capital. However, outsourcing is a common practice, and papers such as Girth (2014) indicate that 70\% of public managers are not satisfied with the performance of outsourced staff, although they do not justify this dissatisfaction. The present work seeks to start filling the gap of literature on the judiciary, further scrutinizing the profiles of human capital.

\section{Productivity}

Performance is a multidimensional concept, whose attributes change throughout time, as well as among stakeholders and organizations (Matitz \& Bulgacov, 2011). Information regarding performance is used by the organizations in order to direct their planning, develop strategies, defend themselves from possible threats, as well as help reach organizational results. Neely, Gregory, and Platts (1995) emphasize that performance supplies the manager with possibilities to measure the organization's actions, such as its productivity capacity, efficiency level, process effectiveness and sales results. Therefore there are several types of performance that are measured in different ways. Due to this perception, i.e., the difficulty to use precise indicators, one can infer significant complexity in the public organization scenario and this is not different in the judiciary.

However, the CNJ in Justiça em Números report simplified the work of the present authors when it specified the way it measured productivity, considering the indicator Number of processes filed. This is the approach used in the present work and that which will be discussed in future papers, which may encompass other common judiciary nuances, as suggested by Akutsu and Guimarães (2012) including judgment time, process cost, and sentence quality. Yeung and Azevedo (2011) analyzed the efficiency of the Brazilian courts of law using Enveloping Data Analysis (DEA), indicating that efficiency varied in the 27 state courts in the country. The study indicates that court efficiency is correlated with judicial management performance, meaning that efficient courts are those that better manage their resources. 


\section{Causal Relationship Between IT Investments and Productivity}

Insights into the causal paths linking IT investments and organizational productivity are studied extensively in other types of organizations, such as hospitals (Caldeira, Serrano, Quaresma, Pedron, \& Romão, 2012), iron and steel, land and space transport, and banks (Sircar, Turnbow, \& Bordoloi, 2000). Therefore, there are studies in the private area on IT investment and productivity that support the existence of a relationship among these constructs, although it is pointed out as an "eternal question" by Trkman (2010, p. 131). In the context of the judiciary, the results found in studies such as the work of Gomes and Guimarães (2013) affirm that there is no empirical evidence on the effect of IT on productivity and court speed. In this context, Sousa (2015) also points out that this hypothesis has not been confirmed for the scope of labor justice. Based on this discussion, we state the following initial hypothesis:

H1. IT investments have a direct and positive effect on the productivity of State Courts of Justice.

\section{Causal Relationship Between Amount of Human Capital and Productivity}

According to behavioral psychology (Blau, 1985; Carson et al., 1995), some constructs may explain different results of human capital in relation to productivity in organizations, focusing mainly on affectivity constructs, such as motivation with career, career commitment, organizational commitment, job satisfaction and satisfaction with promotion. These constructs are not the concern as in the present work, which is to find out what is the human capital profile, whether it is own and/or outsourced that result in greater productivity in the judiciary scenario.

Nogueira, Oliveira, Vasconcelos and Oliveira (2012) affirm that there has been an increase in national court productivity, but there is no consensus about what their most important antecedents are. Research on productivity in the judiciary examined the role of judges and their relationship with productivity (Mitsopoulos \& Pelagidis, 2007; Sousa, 2015). This last work considers other factors such as judges' age and workload, and exposes the complexity of the relationship between the number of judges and the productivity. It is possible that by adding new judges, the workload decreases for existing ones, thereby reducing productivity. Similar views were expressed by Fochezatto (2013). It is understood that the pressure caused by the increase in judges' workload impacts performance (Dimitrova-Grajzl et al., 2012), and the workload is explained as the number of processes not ended in relation to the number of judges. Mitsopoulos and Pelagidis (2007) point out the lack of management as the main factor that negatively impacts productivity in judiciary, despite other options, such as the amount of human capital and any kind of investments.

In the context of knowledge-based organizations, such as judiciary organizations, Mehralian, Reza, Akhavan, and Rajabzadeh (2013) argue that human capital has become a critical factor for longterm productivity and performance. Based on this finding, the present study differentiated own and outsourced human capital, the latter related to contracts with a limited period, which normally do not exceed four years. Therefore, we propose a second hypothesis:

H2. The amount of own human capital (judges, employees, and commissioners) has a positive and direct effect on the productivity of State Courts of Justice.

Outsourcing has become a common practice in Public Administration, especially in middle-level activities. Girth (2014) indicates that the performance of outsourced staff is not always evaluated as positive. The present paper seeks to fill the gap in the literature on the judiciary by looking further into the profiles of human capital. Considering the literature and the outsourcing of activities in public administration, the present study differentiated own human capital itself from outsourced capital, the 
latter related to contracts with a limited period, which normally do not exceed four years. Therefore, we propose our third hypothesis:

H3. The amount of outsourced human capital has a positive and direct effect on the productivity of the State Courts of Justice.

Productivity does not present general measures that can be adopted by all courts. Yeung and Azevedo (2011) use the workload to evaluate court productivity in order to understand variations in each state. Some research advances in comparative analysis point to features of more and less efficient courts, major sources of efficiency or inefficiency, or suggestions for improvement to achieve a certain level of efficiency. Peyrache and Zago (2016) analyzed the efficiency of Italian courts of law in 20032008 , pointing out that technical inefficiency is about $40 \%$ of total inefficiency, court size is $25 \%$ and inefficiency of re-allocation is about 35\%, suggesting that the adoption of best practices can increase efficiency. Although some research focuses only on the productivity of judges (Deyneli, 2012; Schneider, 2005) and the present study differentiates between own and outsourced human capital. These works discuss performance differences related to educational level, age, experience, and wages.

Almklov and Antonsen (2014) offer insight into the complex influences related to the reliability of outsourced work, and the literature that questioned the market oriented organizational models of New Public Administration reforms. Just as in a mathematical hypothesis, that is, without conceptual support, we also propose that:

H4. The amount of own human capital has a positive and direct effect on productivity greater than the amount of outsourced human capital.

These hypotheses emerge as the hypothetical model presented in Figure 1:

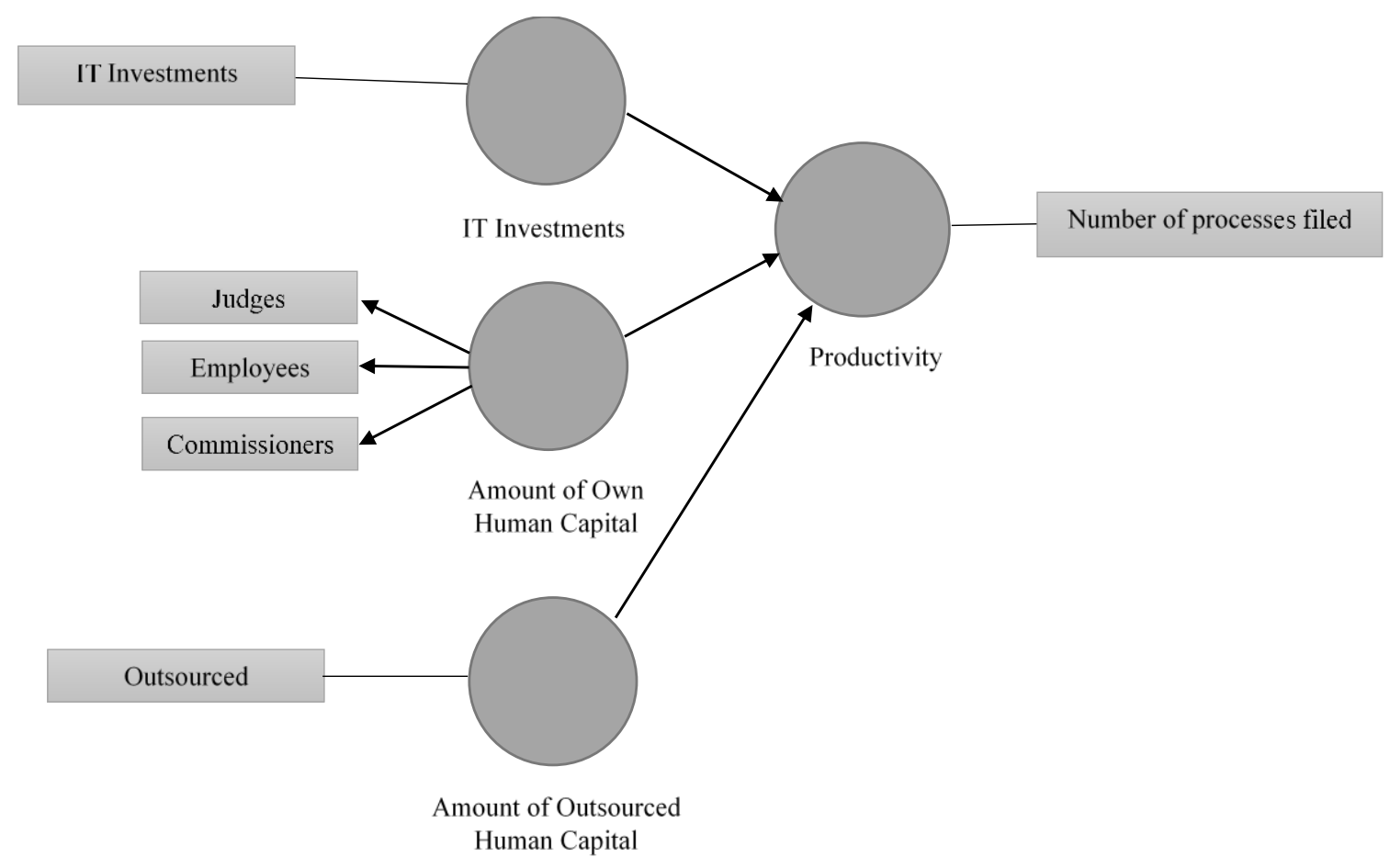

Figure 1. Research Model Source: Prepared by the authors. 


\section{Methodological Procedure}

\section{Data and measurements}

In order to test the hypotheses, we used secondary data, without additional treatments, from the Justiça em Números CNJ report, made available on the Brazilian website (CNJ, 2016), totaling ( $\mathrm{n}=$ 189) records from 27 states that provided information for seven years, from 2009 to 2015. Data were lost in three registers for the variable dinf1, about IT investments representing only $1.6 \%$ of the population, which according to Hair, Black, Babin, Anderson, and Tatham (2009) can be classified as lost and non-skippable data, understood as random. Because they represent less than $10 \%$ of the sample, the substitution was chosen by the respective means.

Table 1 shows the descriptive statistics, where the codes referenced by the Justiça em Números report and the variables that appear in the measurement model in Figure 2 are also shown.

Table 1

Descriptive Statistics

\begin{tabular}{|c|c|c|c|c|c|c|c|c|c|}
\hline & \multirow{2}{*}{$\begin{array}{c}\mathrm{N} \\
\text { Statistic }\end{array}$} & \multirow{2}{*}{$\begin{array}{c}\text { Minimum } \\
\text { Statistic }\end{array}$} & \multirow{2}{*}{$\begin{array}{c}\text { Maximum } \\
\text { Statistic }\end{array}$} & \multirow{2}{*}{$\begin{array}{c}\text { Mean } \\
\text { Statistic }\end{array}$} & \multirow{2}{*}{$\begin{array}{c}\begin{array}{c}\text { Std. } \\
\text { Deviation }\end{array} \\
\text { Statistic }\end{array}$} & \multicolumn{2}{|c|}{ Skewness } & \multicolumn{2}{|c|}{ Kurtosis } \\
\hline & & & & & & Statistic & $\begin{array}{l}\text { Std. } \\
\text { Error }\end{array}$ & Statistic & $\begin{array}{l}\text { Std. } \\
\text { Error }\end{array}$ \\
\hline $\begin{array}{l}\text { dinf1 - IT } \\
\text { Investments }\end{array}$ & 189 & 70750 & 275096046 & 14257746.54 & 33777891.400 & 5.560 & .177 & 34.654 & .352 \\
\hline mag - Judges & 189 & 31 & 2566 & 418.93 & 477.485 & 3.087 & .177 & 10.758 & .352 \\
\hline $\begin{array}{l}\text { tbaix - } \\
\text { Number of } \\
\text { processes filed }\end{array}$ & 189 & 31113 & 5937348 & 697290.42 & 1052595.298 & 3.165 & .177 & 10.835 & .352 \\
\hline $\begin{array}{l}\text { tfauxc- } \\
\text { Outsourced }\end{array}$ & 189 & 0 & 5542 & 341.31 & 767.027 & 4.278 & .177 & 21.482 & .352 \\
\hline $\begin{array}{l}\mathrm{cc}- \\
\text { Commissioners }\end{array}$ & 189 & 167 & 12905 & 1326.30 & 2066.746 & 4.505 & .177 & 20.626 & .352 \\
\hline $\begin{array}{l}\text { serv - } \\
\text { Employees }\end{array}$ & 189 & 677 & 46291 & 6423.95 & 8480.788 & 3.599 & .177 & 13,748 & .352 \\
\hline
\end{tabular}

Note. the total number of the sample is 189 , but 9 outliers were identified, the calculations were made without the presence of outliers. Source: Prepared by the authors.

To analyze the presence of outliers, according to Hair et al. (2009), the Mahalanobis D $\mathrm{D}^{2}$ distance was calculated by means of a linear regression, taking the dependent variable Number of Processes filed, and using the other five independent variables and then measuring using the SPSS function CDF.CHISQ. This returns the probability of one value to use a Chi-Square distribution with a certain degree of freedom, in this case five. A p-value of less than 0.001 was obtained, eliminating the data of the Rio de Janeiro Court of Justice (Tribunal de Justiça do Estado do Rio de Janeiro [TJRJ]) for the years 2009 and 2010, and the São Paulo Court of Justice (Tribunal de Justiça do Estado de São Paulo TJSP) from all seven years that were considered outliers, thus leaving us 180 records.

\section{Results Analysis}

We performed the empirical testing of the theoretical hypotheses by using structural equation modeling (SEM). According to Hair et al. (2009), the characteristic of the sample with non-normal data 
added to the fact that the model has three latent variables, and therefore several interrelated dependency relations led to the use of SEM. In this context, SmartPLS software (version 3.2.4) was chosen, which provides the statistical method of the Partial Least Squares (PLS), which requires relatively few records, the minimum being indicated by Hair, Hult, Ringle, and Sarstedt (2017) as 10 times the highest number of arrows pointing to any latent variable. In this case 30 registers is enough. The PLS algorithm was executed with the default values following the guidelines of Hair et al. (2017), resulting in Figure 2.

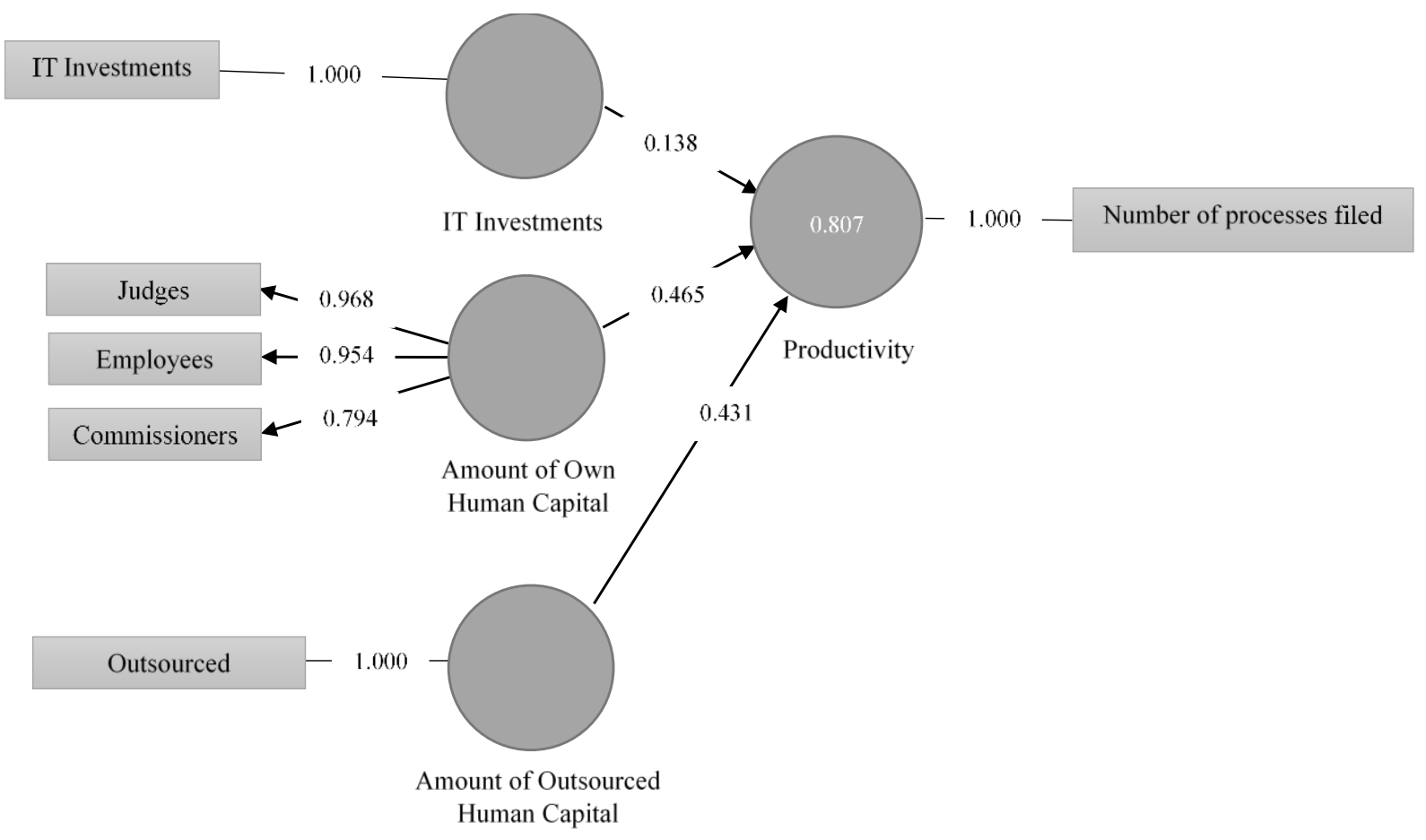

Figure 2. PLS Algorithm Results

Source: Prepared by the authors.

The only construct with more than one variable was built as reflexive, because of its characteristics. The results of the measurement model regarding the validity and reliability of this construct are shown in Table 2, presenting Cronbach's alpha and composite reliability, greater than 0.7 and AVE, greater than 0.5 . The external loads of convergent validity are greater than 0.7 .

Table 2

\section{Reflexive Measurement Model}

\begin{tabular}{lccc}
\hline & Cronbach's Alpha & $\begin{array}{c}\text { Composite } \\
\text { Reliability }\end{array}$ & $\begin{array}{c}\text { Average Variance } \\
\text { Extracted (AVE) }\end{array}$ \\
\hline Amount of Own Human Capital & 0.895 & 0.934 & 0.826 \\
\hline
\end{tabular}

Note. Source: Prepared by the authors.

Still on the measurement model, analyzing discriminant validity is presented (Table 3) with the Fornell-Larcker criterion, according to which the square root of the AVE must be greater than the loads of the other constructs, which was proven. The cross-loading test also showed no problem. 
Table 3

\section{Fornell-Larcker Criterion}

\begin{tabular}{lcccc}
\hline & $\begin{array}{c}\text { Amount of } \\
\text { Outsourced Human } \\
\text { Capital }\end{array}$ & $\begin{array}{c}\text { Amount of } \\
\text { Own Human } \\
\text { Capital }\end{array}$ & $\begin{array}{c}\text { IT } \\
\text { Investments }\end{array}$ & Productivity \\
\hline $\begin{array}{l}\text { Amount of Outsourced Human } \\
\text { Capital }\end{array}$ & 1.000 & 0.909 & & \\
\hline Amount of Own Human Capital & 0.656 & 0.622 & 1.000 & 1.000 \\
\hline IT Investments & 0.363 & 0.833 & 0.584 & 1.786 \\
\hline Productivity & 0.786 & & \\
\hline
\end{tabular}

Note. Source: Prepared by the authors.

Still, according to Hair et al. (2017), the first step of the structural model is to evaluate collinearity using the VIF indicator, using as a parameter less than 5, with the highest result being 2.496. On the second step, coefficients are evaluated using the Bootstrapping procedure with 5000 subsamples with the option no sign changes. Table 4 shows that all coefficients are significant ( $p$-value $<0.05)$ with productivity.

Table 4

\section{Bootstrapping Path Coefficients}

\begin{tabular}{lcccc}
\hline & $\begin{array}{c}\text { Original } \\
\text { Sample (O) }\end{array}$ & $\begin{array}{c}\text { Standard Deviation } \\
\text { (STDEV) }\end{array}$ & $\begin{array}{c}\text { T Statistics } \\
(\mid \mathbf{O} / \text { STDEV|) }\end{array}$ & P Values \\
\hline $\begin{array}{l}\text { Amount of Outsourced Human } \\
\text { Capital -> Productivity }\end{array}$ & 0.431 & 0.075 & 5.741 & 0.000 \\
\hline $\begin{array}{l}\text { Amount of Own Human Capital -> } \\
\text { Productivity }\end{array}$ & 0.465 & 0.066 & 7.077 & 0.000 \\
\hline IT Investments -> Productivity & 0.138 & 0.070 & 1.965 & 0.049 \\
\hline
\end{tabular}

Note. Source: Prepared by the authors.

The third step is to evaluate the determination coefficient that measures the model predictive accuracy. The result was 0.807 , with an adjusted value of 0.803 , which is considered substantial by Hair, Ringle, and Sarstedt (2011). In step four, it seeks to measure the size of the effect $\mathrm{f}^{2}$ that evaluates if any omitted constructs generate substantive impact on the endogenous constructs, the result is that IT investment has a small effect on the endogenous construct productivity.

Table 5

\section{Omitted Constructs}

\begin{tabular}{ll}
\hline f Square & Productivity \\
\hline Amount of Outsourced Human Capital & 0.543 \\
\hline Amount of Own Human Capital & 0.448 \\
\hline IT Investments & 0.060 \\
\hline
\end{tabular}

Note. Source: Prepared by the authors. 
In the fifth step, the predictive relevance is evaluated using the Blindfolding algorithm with default configuration, omission distance equal to seven, result in a $\mathrm{Q}^{2}$ that represents great relevance, greater than the 0.35 parameter of Hair et al. (2011), as demonstrated in Table 6.

Table 6

Blindfolding

\begin{tabular}{lccc}
\hline & SSO & SSE & Q $^{\mathbf{2}}$ (=1-SSE/SSO) \\
\hline Amount of Outsourced Human Capital & 180.000 & 180.000 & \\
\hline Amount of Own Human Capital & 540.000 & 540.000 & \\
\hline IT Investments & 180.000 & 180.000 & \\
\hline Productivity & 180.000 & 35.531 & 0.803 \\
\hline
\end{tabular}

Note. Source: Prepared by the authors.

Another test was to analyze the graphs of the IT investment construct as a moderating effect on the relationships between own and outsourced human capital and productivity (Figure 3).

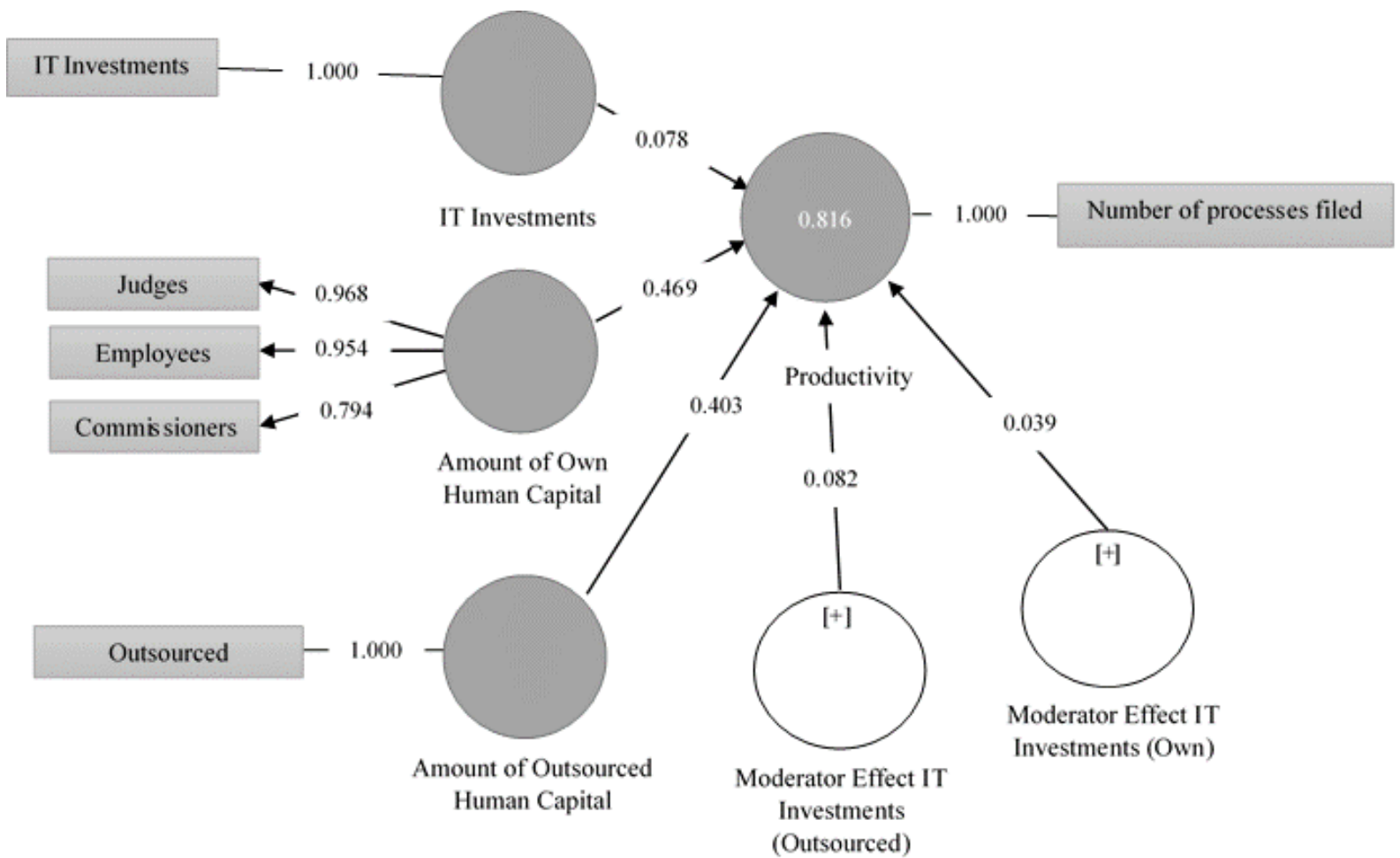

Figure 3. Moderator Effect Test of IT Investment and Productivity for Both Exogenous Constructs Source: Prepared by the authors.

Despite the apparent moderating effect observed in Figures 3, 4, and 5, after some Bootstrapping executions with (a) own human capital, (b) outsourced human capital, and (c) both constructs, with the endogenous construct productivity, the result was that all of them were non-significant, (a) 0.481 , (b) 0.090 , (c) 0.428 and 0.609 . This evaluation of possible moderating effects was discarded from the initial discussion. However, it was requested after analysis by a quantitative methods specialist in order to give greater robustness to the continuation of the present work that will improve the relationship between IT investments and productivity constructs in future papers. 


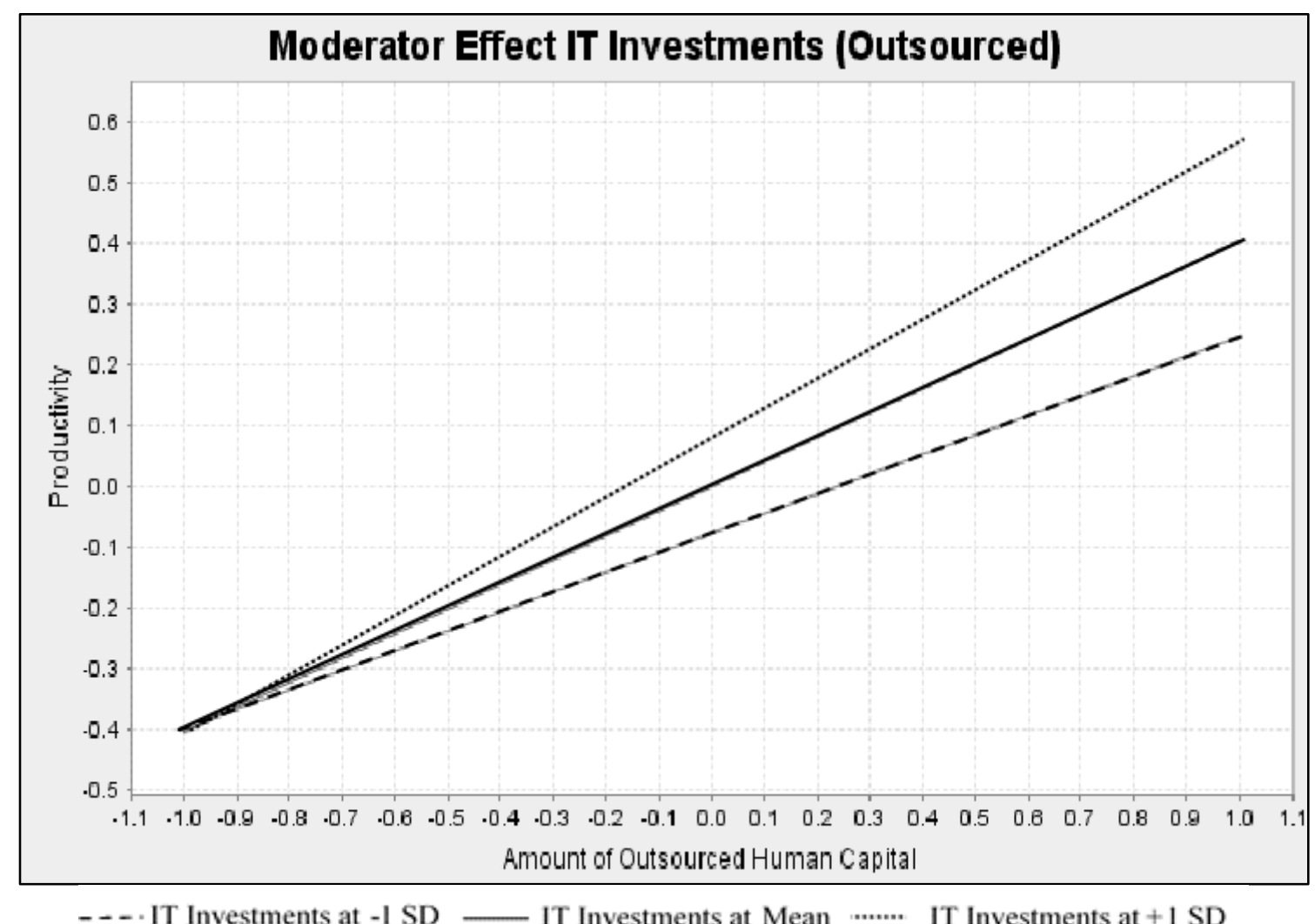

Figure 4. Moderator Effect Test of IT Investment and Outsourced Human Capital Source: Prepared by the authors.

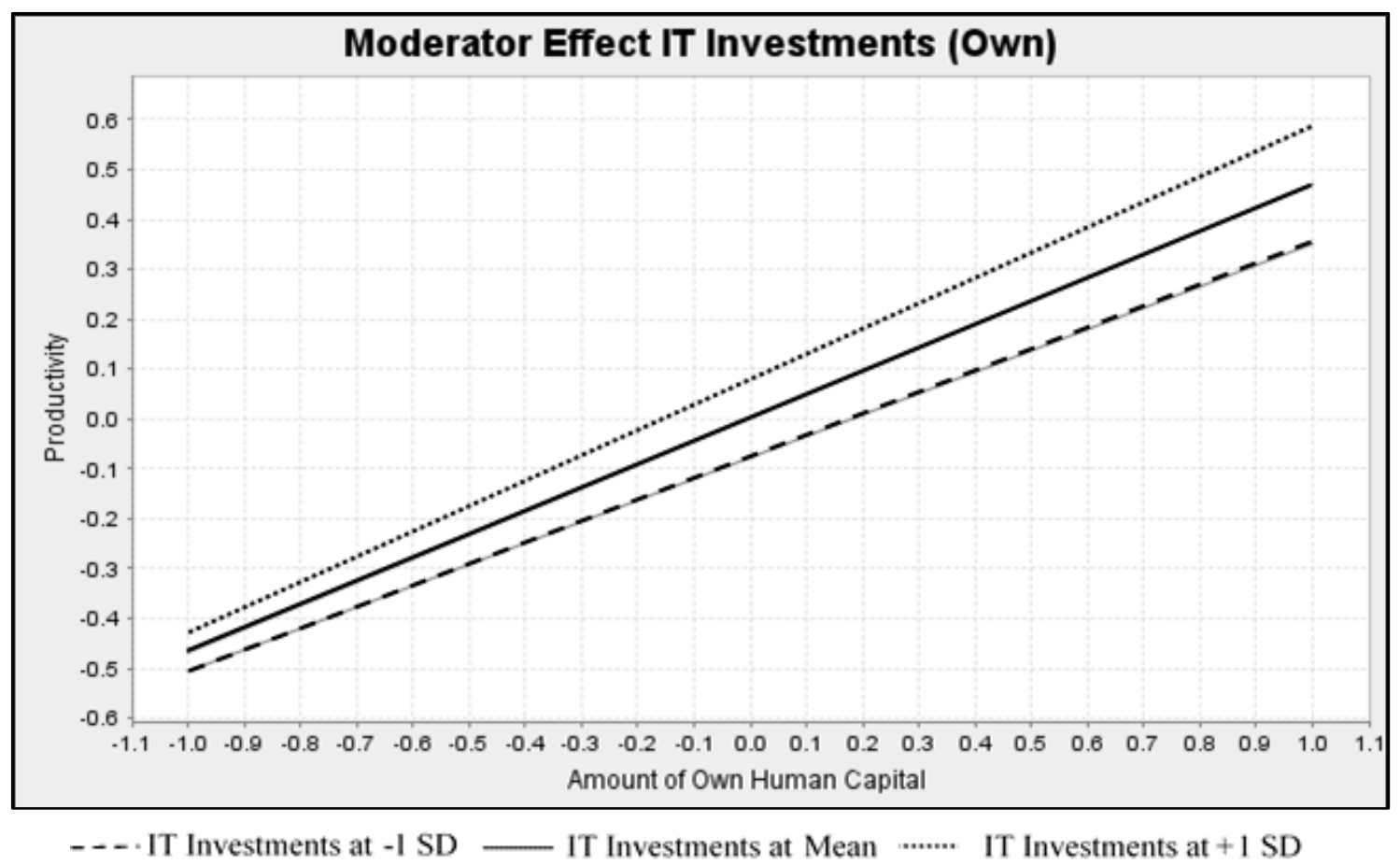

Figure 5. Moderator Effect Test of IT Investment and Own Human Capital Source: Prepared by the authors.

The final analysis was a t-test for coefficients means using 5,000 samples of Bootstrapping, between own human capital and the productivity effect $(\mathrm{H} 2)$ and outsourced human capital and the 
productivity effect (H3). The difference between the means was statistically significant, according to results presented in Table 7.

Table 7

Independent Sampling Test

\begin{tabular}{|c|c|c|c|c|c|c|}
\hline & & \multicolumn{2}{|c|}{$\begin{array}{l}\text { Levene's Test } \\
\text { for Quality of } \\
\text { Variance }\end{array}$} & \multicolumn{3}{|c|}{ t-test for Equality of Means } \\
\hline & & $\mathrm{F}$ & Sig. & $\mathrm{t}$ & $\mathrm{df}$ & Sig. (2-tailed) \\
\hline \multirow[t]{2}{*}{ Own X Outsourced } & $\begin{array}{l}\text { Equal variances } \\
\text { assumed }\end{array}$ & .167 & .682 & 114.933 & 9998 & 0.000 \\
\hline & $\begin{array}{l}\text { Equal variances } \\
\text { not assumed }\end{array}$ & & .682 & 114.933 & 9997.781 & 0.000 \\
\hline
\end{tabular}

Note. Source: Prepared by the authors.

SEM analysis resulted in the confirmation of all four hypothesis, as synthesized in Table 8.

Table 8

Research Hypothesis

\begin{tabular}{lll}
\hline Hypothesis & Description & Results \\
\hline $\mathrm{H}_{1}$ & $\begin{array}{l}\text { IT investments have a direct and positive effect on the } \\
\text { productivity of State Courts of Justice. }\end{array}$ & Confirmed \\
\hline $\mathrm{H}_{2}$ & $\begin{array}{l}\text { The amount of own human capital (judges, employees, and } \\
\text { commissioners) has a positive and direct effect on the } \\
\text { productivity of State Courts of Justice. }\end{array}$ & \\
\hline $\mathrm{H}_{3}$ & $\begin{array}{l}\text { The amount of outsourced human capital has a positive and } \\
\text { direct effect on the productivity of the State Courts of Justice }\end{array}$ & \\
\hline $\mathrm{H}_{1}$ & $\begin{array}{l}\text { The amount of own human capital has a positive and direct } \\
\text { effect on productivity greater than the amount of outsourced } \\
\text { human capital. }\end{array}$ & \\
\hline
\end{tabular}

Note. Source: Prepared by the authors.

\section{Conclusions}

The results contribute to the scarce empirical literature on the productivity of courts in Brazil, especially with the analysis of the Justiça em Números report that was released in 2004, but only in 2012 with the current level of detail. Public sector performance surveys are often taking a descriptive or normative stance, normally without a strong and clear reference to theories. Existing empirical evidence on the productivity antecedents of judiciary is still rather limited and often inconclusive. In this sense an incremental approach may be interesting for construction of parsimonious models involving new constructs, or even removing constructs that do not influence their measurements.

The contribution of this article with the existing literature is to confirm the perception of Gomes and Guimarães (2013) that already pointed out financial and human capital as most important in the studies reviewed by these authors, and that financial resources would not be directly related to productivity, and human capital would be related to productivity in a controversial way. But beyond the 
existing literature, the present work makes advances in relation to IT investments and human capital issues. Among other empirical contributions, by knowing the impact of the variables, it is possible to direct reforms of these courts.

In the New Public Administration context, the work of Moynihan and Hawes (2012) examines the use of performance information as a behavioral measure in administrative reforms. These authors assume that if performance information is used, then decision-making processes are better. In this direction, they urge public managers to seek a greater knowledge of causal relationships that affect judicial productivity. These authors also affirm the importance of the involvement of the various stakeholders in the performance measurement process, so several constructs need to be evaluated in future research.

Consistent with the call of the national literature for more research using statistical indicators in the judiciary scenario, the contribution of this paper was taking a step to fill the literature gap. Discussing what are the antecedent constructs of state court productivity and investigating direct links to performance, we concluded that all constructs included in the theoretical model (own human capital, outsourced human capital, IT investments) impact Brazilian Courts' productivity. In addition, although the results have taken data from all state courts, further studies are needed to identify whether there is heterogeneity between these courts depending on their geographic location and size. A prominent work in this direction is Gomes, Guimarães, and Akutsu, (2017) about São Paulo’s state court

With respect to the first hypothesis about the impact of IT investments on productivity, it is understood that its confirmation is consistent with an updated literature review (Aalst, La Rosa, \& Santoro, 2016) and even with classics (Hammer, 1990) from the area of business process automation, whose constructs could not be operationalized using only the data from the Justiça em Números report. These works point to IT investments as an enabling factor for the improvement of organizational processes and these, in turn, as sources of improvement of organizational performance.

The rejection of IT investment moderation tests in causal relationship between the two constructs of human capital and productivity can be explained by the content validity of the used construct that concerns the amounts of money invested in IT. Such investment is used for all sorts of acquisitions that IT may be involved with, such as end-user hardware, information security assets, application servers, database servers, application software, network assets - not just investments in information systems that are effectively embedded in the daily routines of human capital that can influence their productivity. Constructs related to the use of information systems, or level of automation of business processes, will be in future works.

Regarding the importance of own human capital and outsourced human capital for productivity, both $\mathrm{H} 2$ and $\mathrm{H} 3$ were confirmed, and this leads to the possibility of an evaluation of the use of a general construct called human capital that would cover all profiles.

Regarding the H4 Hypothesis, a more careful analysis is needed despite it being confirmed. The confirmation can conclude a difference in the size of the effect of one against the other $(\mathrm{H} 2>\mathrm{H} 3)$. However, it is not possible to infer that $\mathrm{H} 3$ can be neglected because both human capital profiles have a great correlation with productivity in the context of State Courts of Justice for the years studied (2009 to 2015). Table 5 shows an important finding of the effect of $\mathrm{f}^{2}$ related to the size of the causality relation in the case of omission of other constructs, arriving at the conclusion that both human capital profiles can be considered important for explaining productivity in the judiciary. Future research is encouraged to test these causal relationships using other statistical methods, as well as the need to better understand the apparent dissatisfaction with outsourced human capital pointed out by Girth (2014).

As an academic contribution, the idea of researching the adoption of statistical data and the reforms of the new public administration by itself, and that they may not result in performance improvements, is not entirely new. But the results on IT investments and outsourcing seem to expand the field in the judiciary context. From the point of view of management of the courts themselves, these results suggest that IT investments need to be planned and that the exchange of own human capital by 
outsourced human capital in simple quantitative terms can be studied, but it is necessary to stress as a limitation of this research the lack of involvement of the different levels of spending of these human capital profiles. Already from the point of view of legislators, such as the CNJ, this study provides a significant indication of the need for greater understanding and possible containment of IT investments currently being carried out. The failures in the implantation of Electronic Judicial System may be a subject for future research, taking into account that the CNJ's IT investments may be misdirected, possibly bypassing those systems that are identified as a critical innovation for the productivity of the national judiciary (Sousa \& Guimarães, 2015).

The focus of the work on performance using only the number of processes filed represents another limitation of the present study, it is understood that several other assignments of human capital and IT investments could be measured, such as the level of transparency and accountability, quality of service to citizens, etc. A future research could include these variables using a survey of the various judiciary stakeholders; e.g., citizens, OAB, defenders, prosecutors, public prosecutors, etc. Despite these limitations, this study represents a start for future papers with a determination coefficient $\left(\mathrm{R}^{2}\right)$ of 0.803 .

For future research, we recommended developing and validating a data collection instrument referencing the variables and constructs of the model of Figure 1 with improved validity and reliability. Some of the limitations of the model may be corrected from tests in surveys with an expanded sample of data, supported in a standardized instrument, whose results may indicate, after the statistical analysis, the variables most adequate to represent the observed reality; that is, those that better allow for empirically measuring an expanded productivity construct or those variables which impact this construct. In addition, qualitative studies are suggested so that other aspects of the productivity of the judicial units and magistrates can be explored.

\section{References}

Aalst, W. M. P. van der, La Rosa, M., \& Santoro, F. M. (2016). Business process management don't forget to improve the process! Business \& Information Systems Engineering, 58(1), 1-6. https://doi.org/10.1007/s12599-015-0409-x

Akutsu, L., \& Guimarães, T. D. A. (2012). Dimensões da governança judicial e sua aplicação ao sistema judicial brasileiro. Revista Direito GV, 8(1), 183-202. https://doi.org/10.1590/S180824322012000100008

Almklov, P. G., \& Antonsen, S. (2014). Making work invisible: New public management and operational work in critical infrastructure sectors. Public Administration, 92(2), 477-492. https://doi.org/10.1111/padm.12069

Beenstock, M., \& Haitovsky, Y. (2004). Does the appointment of judges increase the output of the judiciary? International Review of Law and Economics, 24(3), 351-369. https://doi.org/10.1016/j.irle.2004.10.006

Blau, G. G. (1985). The measurement and prediction of career commitment. Journal of Occupational Psychology, 58(4), 277-288. https://doi.org/10.1111/j.2044-8325.1985.tb00201.x

Bresser-Pereira, L. C. (2009). Os primeiros passos da reforma gerencial do estado de 1995. Revista Eletrônica sobre a Reforma do Estado, (16), 1-36. Retrieved from http://www.direitodoestado.com.br/artigo/luiz-carlos-bresser-pereira/os-primeiros-passos-dareforma-gerencial-do-estado-de-1995

Bronzo, M., de Resende, P. T. V., de Oliveira, M. P. V., McCormack, K. P., de Sousa, P. R., \& Ferreira, R. L. (2013). Improving performance aligning business analytics with process orientation. 
International Journal of Information Management, 33(2), 300-307. https://doi.org/10.1016/j.ijinfomgt.2012.11.011

Caldeira, M., Serrano, A., Quaresma, R., Pedron, C., \& Romão, M. (2012). Information and communication technology adoption for business benefits: A case analysis of an integrated paperless system. International Journal of Information Management, 32(2), 196-202. https://doi.org/10.1016/j.ijinfomgt.2011.12.005

Carson, K. D., Carson, P. P., \& Bedeian, A. G. (1995). Development and construct-validation of a career entrenchment measure. Journal of Occupational and Organizational Psychology, 68(4), 301-320. https://doi.org/10.1111/j.2044-8325.1995.tb00589.x

Cassol, A., Gonçalo, C. R., \& Ruas, R. L. (2016). Redefining the relationship between intellectual capital and innovation: The mediating role of absorptive capacity. Brazilian Administration Review, 13(4), e150067. Retrieved from http://www.scielo.br/pdf/bar/v13n4/1807-7692-bar-13-04e150067.pdf. https://doi.org/10.1590/1807-7692bar2016150067

Conselho Nacional de Justiça. (2016). Justiça em números 2016 (ano-base 2015). Retrieved November 27 , 2016 , from http://www.cnj.jus.br/files/conteudo/arquivo/2016/10/b8f46be3dbbff344931a933579915488.pdf

Decreto-Lei n. 200, de 25 de fevereiro de 1967. (1967). Dispõe sôbre a organização da Administração Federal, estabelece diretrizes para a Reforma Administrativa e dá outras providências. São Paulo: Atlas.

Deyneli, F. (2012). Analysis of relationship between efficiency of justice services and salaries of judges with two-stage DEA method. European Journal of Law and Economics, 34(3), 477-493. https://doi.org/10.1007/s10657-011-9258-3

Dimitrova-Grajzl, V., Grajzl, P., Sustersic, J., \& Zajc, K. (2012). Court output, judicial staffing, and the demand for court services: Evidence from Slovenian courts of first instance. International Review of Law and Economics, 32(1), 19-29. https://doi.org/10.1016/j.irle.2011.12.006

Fochezatto, A. (2013). Gestão pública no poder judiciário: Análise da eficiência relativa dos tribunais estaduais usando o método DEA. Economic Analysis of Law Review, 4(2), 377-390. http://dx.doi.org/10.18836/2178-0587/ealr.v4n2p377-390

Galliers, R., \& Leidner, D. E. (2003). Strategic information management: Challenges and strategies in managing information systems. Oxford: Butterworth-Heinemann.

Girth, A. M. (2014). Strengthening contract management capacity to ensure accountability. Journal of Public Administration, 24(3), 795-799. https://doi.org/10.1093/jopart/mut055

Gomes, A. O., \& Guimarães, T. A. (2013). Desempenho no Judiciário. Conceituação, estado da arte e agenda de pesquisa. Revista de Administração Pública, 47(2), 379-401. https://doi.org/10.1590/s0034-76122013000200005

Gomes, A. O., Guimarães, T. A., \& Akutsu, L. (2017). Court caseload management: The role of judges and administrative assistants. Revista de Administração Contemporânea, 21(5), 648-665. Retrieved form http://www.scielo.br/pdf/rac/v21n5/1415-6555-rac-21-05-00648.pdf. http://dx.doi.org/10.1590/1982-7849rac2017160179

Hair, J. F., Black, W. C., Babin, B. J., Anderson, R. E., \& Tatham, R. L. (2009). Analise multivariada de dados (6a ed.). Porto Alegre: Bookman.

Hair, J. F., Hult, G. T. M., Ringle, C. M., \& Sarstedt, M. (2017). A primer on partial least squares structural equation modeling (PLS-SEM) (2nd ed.). Thousand Oaks, CA: Sage Publications 
Hair, J. F., Ringle, C. M., \& Sarstedt, M. (2011). PLS-SEM: Indeed a silver bullet. Journal of Marketing Theory and Practice, 19(2), 139-152. https://doi.org/10.2753/MTP1069-6679190202

Hammer, M. (1990, July/August). Reengineering work: Don't automate, obliterate. Harvard Business Review, 104-112. Retrieved from https://hbr.org/1990/07/reengineering-work-dont-automateobliterate

Heeley, M. B., \& Jacobson, R. (2008). The recency of technological inputs and financial performance. Strategic Management Journal, 29(7), 723-744. https://doi.org/10.1002/smj.682

Ippoliti, R., Melcarne, A., \& Ramello, G. B. (2015). Judicial efficiency and entrepreneurs' expectations on the reliability of European legal systems. European Journal of Law and Economics, 40(1), 7594. https://doi.org/10.1007/s10657-014-9456-x

Matitz, Q. R. S., \& Bulgacov, S. (2011). O conceito desempenho em estudos organizacionais e estratégia: Um modelo de análise multidimensional. Revista de Administração Contemporânea, 15(4), 580-607. https://doi.org/10.1590/S1415-65552011000400003

Mehralian, G., Reza, H., Akhavan, P., \& Rajabzadeh, A. (2013). Prioritization of intellectual capital indicators in knowledge-based industries: Evidence from pharmaceutical industry. International Journal of Information Management, 33(1), 209-216. https://doi.org/10.1016/j.ijinfomgt.2012.10.002

Mitsopoulos, M., \& Pelagidis, T. (2007). Does staffing affect the time to dispose cases in Greek courts? International Review of Law and Economics, 27(2), 219-244. https://doi.org/10.1016/j.irle.2007.06.001

Mohamed, N. (2012). A conceptual framework for information technology governance effectiveness in private organizations. Information Management \& Computer Security, 20(2), 88-106. https://doi.org/10.1108/09685221211235616

Moynihan, D. P., \& Hawes, D. P. (2012). Responsiveness to reform values: The influence of the environment on performance information use. Public Administration Review, 72(S1), 95-105. https://doi.org/10.111/j.1540-6210.2012.02653.x.Responsiveness

Neely, A. D., Gregory, M. J., \& Platts, K. W. (1995). Performance measurement system design: A literature review and research agenda. International Journal of Operations \& Production Management, 15(4), 80-116. https://doi.org/10.1108/01443579510083622

Nogueira, J. M. M., Oliveira, K. M. M. de, Vasconcelos, A. P. de, \& Oliveira, L. G. L. (2012). Estudo exploratório da eficiência dos Tribunais de Justiça estaduais brasileiros usando a análise envoltória de dados (DEA). Revista de Administração Pública, 46(5), 1317-1340. https://doi.org/10.1590/s0034-76122012000500007

Oliveira, F. L. de. (Org.). (2012). Justiça em foco: Estudos empíricos. Rio de Janeiro: Editora FGV.

Peyrache, A., \& Zago, A. (2016). Large courts, small justice!: The inefficiency and the optimal structure of the Italian justice sector. Omega, 64, 42-56. https://doi.org/10.1016/j.omega.2015.11.002

Sadek, M. (2004). Poder Judiciário: Perspectivas de reforma. Opinião Pública, 10(1), 1-62. https://dx.doi.org/10.1590/S0104-62762004000100002

Sadek, M. T., \& Oliveira, F. L. (2012). Estudos, pesquisas e dados em Justiça. In F. L. de.Oliveira (Org.), Justiça em foco: Estudos empíricos (pp. 15-61). Rio de Janeiro: Editora FGV.

Schneider, M. R. (2005). Judicial career incentives and court performance: An empirical study of the German labor courts of appeal. European Journal of Law and Economics, 20(2), 127-144. https://doi.org/10.1007/s10657-005-1733-2 
Sircar, S., Turnbow, J. L., \& Bordoloi, B. (2000). A framework for assessing the relationship between information technology investments and firm performance. Journal of Management Information System, 16(4), 69-97. https://doi.org/10.1080/07421222.2000.11518266

Sousa, M. de M. (2015). Inovação, recursos e desempenho em tribunais do trabalho (Tese de doutorado). Universidade de Brasília, Brasília, DF, Brasil. Retrieved from http://repositorio.unb.br/handle/10482/18790

Sousa, M. de M., \& Guimarães, T. A. (2015). The adoption of innovations in Brazilian labor courts from the perspective of judges and court managers. Revista de Administração, 52(1), 103-113. https://doi.org/10.1016/j.rausp.2016.09.008

Trkman, P. (2010). The critical success factors of business process management. International Journal of Information Management, 30(2), 125-134. https://doi.org/10.1016/j.ijinfomgt.2009.07.003

Yeung, L. L., \& Azevedo, P. F. (2011). Measuring efficiency of Brazilian courts with data envelopment analysis (DEA). IMA Journal of Management Mathematics, 22(4), 343-356. https://doi.org/10.1093/imaman/dpr002

\title{
Authors' Profiles
}

\author{
Alamir Costa Louro \\ Av. Fernando Ferrari, 514, Goiabeiras, 29075-910, Vitória, ES, Brazil. E-mail address: alamirlouro@ gmail.com. \\ http://orcid.org/0000-0002-9947-6353 \\ Washington Romão Santos \\ Av. Fernando Ferrari, 514, Goiabeiras, 29075-910, Vitória, ES, Brazil. E-mail address: washington_romao@hotmail.com. \\ http://orcid.org/0000-0002-6476-6318 \\ Helio Zanquetto Filho \\ Av. Fernando Ferrari, 514, Goiabeiras, 29075-910, Vitória, ES, Brazil. E-mail address: zanquetto@gmail.com
}

